Article

\title{
Applications of Prodigiosin Extracted from Marine Red Pigmented Bacteria Zooshikella sp. and Actinomycete Streptomyces sp.
}

\author{
Chatragadda Ramesh 1,2,*(D), Nambali Valsalan Vinithkumar ${ }^{2}$, Ramalingam Kirubagaran ${ }^{3}$ \\ Chidambaram Kulandaisamy Venil ${ }^{4}$ (D) and Laurent Dufossé ${ }^{5, * \text { (D) }}$ \\ 1 National Institute of Oceanography (CSIR-NIO), Dona Paula 403004, India \\ 2 Atal Centre for Ocean Science and Technology, ESSO-NIOT, Dollygunj, Port Blair, \\ Andaman and Nicobar Islands 744103, India; vinith@niot.res.in \\ 3 Marine Biotechnology Group, ESSO-National Institute of Ocean Technology (NIOT), \\ Ministry of Earth Sciences (Govt. of India), Chennai 600100, India; kirubagar@gmail.com \\ 4 Department of Biotechnology, Anna University, Coimbatore 641046, India; ckvenil@gmail.com \\ 5 Chemistry and Biotechnology of Natural Products, CHEMBIOPRO, Université de La Réunion, \\ ESIROI Agroalimentaire, 15 Avenue René Cassin, F-97744 Saint-Denis CEDEX 9, France \\ * Correspondence: chramesh@nio.org (C.R.); laurent.dufosse@univ-reunion.fr (L.D.); \\ Tel.: +91-(0)-3192-225083/95 (C.R.); +33-262217544 (L.D.)
}

Received: 26 March 2020; Accepted: 9 April 2020; Published: 13 April 2020

check for updates

\begin{abstract}
This study is aimed to determine the distribution, diversity and bioprospecting aspects of marine pigmented bacteria (MPB) isolated from pristine Andaman Islands, India. A total of 180 samples including seawater, sediment, marine plants, invertebrates, and vertebrates were collected and investigated for isolating pigmented bacteria. Results revealed that sediment, invertebrates, and seawater samples were colonized with a greater number of pigmented bacteria pertains to $27.9 \times 10^{3} \mathrm{CFU} / \mathrm{mL}, 24.1 \times 10^{3} \mathrm{CFU} / \mathrm{mL}$ and $6.7 \times 10^{3} \mathrm{CFU} / \mathrm{mL}$ respectively. Orange $\left(21.6 \times 10^{3} \mathrm{CFU} / \mathrm{mL}\right)$ and red $\left(8.0 \times 10^{3} \mathrm{CFU} / \mathrm{mL}\right) \mathrm{MPB}$ were predominant than other pigmented bacteria. Fourteen potential MPB were selected based on their intense pigmentation and tested for bioactive nature and food colorant applications. Out of 14, two red pigmented strains BSE6.1 \& S2.1 displayed potential multifaceted applications, such as antibacterial, antioxidant, food colorant, and staining properties. Brown pigmented strains $\mathrm{CO} 8$ and yellow pigmented strain SQ2.3 have displayed staining properties. Chemical characterization of red pigment using TLC, HP-LC, GC-MS, FT-IR and ${ }^{1} \mathrm{H}-\mathrm{NMR}$ analysis revealed prodigiosin as a main chemical constituent. Pure form of prodigiosin compound fractions obtained from both the strains displayed effective antibacterial activity against different human pathogens. MIC and MBC assays revealed that S2.1 requires $300 \mu \mathrm{g}$ and $150 \mu \mathrm{g}$, respectively, and BSE6.1 require $400 \mu \mathrm{g}$ concentrations of pigment compound for complete inhibition of S. aureus subsp. aureus. On the basis of 16S rRNA sequence analysis, strains S2.1 and BSE6.1 were identified as Zooshikella sp. and Streptomyces sp. and assigned under the GenBank accession numbers: MK680108 and MK951781 respectively.
\end{abstract}

Keywords: Zooshikella sp.; Streptomyces sp.; marine sediment; antibacterial activity; prodigiosin

\section{Introduction}

Marine bacterial communities are known to play an important role in regulation of ecological and biogeochemical processes and shaping the biosphere [1]. Some microorganism has enormous potentiality to produce diverse striking traits such as production of pigments and biomolecules etc. Pigment production in some microbes is regulated via the quorum sensing mechanism [2]. Several marine pigmented bacterial species have demonstrated various biological activities such as 
antimicrobial, anticancer and immunosuppressive activities [3]. Recent studies on natural products and microbial autecology science have increased requisite demand on investigating novel and alternative resources for eco-friendly and aesthetic natural products like bacterial pigments for different biomedical and industrial applications.

Unlike pigmentation in terrestrial bacteria, marine pigmented bacteria display a wide array of pigment hues including black, brown, golden, indigo, silver, red, yellow, blue, violet, green, orange and fluorescent green [4,5]. In the past five decades, over more than 10,000 marine microbial metabolites have been characterized [6]. However, pigment molecules from marine bacteria are poorly understood and extensive studies are yet to be focused on this aspect. In recent research, microbial pigments are emphasized as unending and untapped natural sources for the applications of food grade pigments, antimicrobial, antidiabetic, anticancer and antiulcer agents for pharmaceutical industries [7]. Currently, scientists and food industries are seeking for such natural pigments from marine bacteria due to their biological functional attributes. These molecules are not fully explored from marine microbes and are still untouched when compared to microbes of terrestrial origin.

Several marine Gram-positive and Gram-negative bacteria produce pigments on usual culture media. The characteristics of these bacteria resemble members of the genera Alteromonas, Corynebacterium, Flavobacterium, and Pseudomonas [4]. The awareness of natural products and microbial autecology science has increased requisite demand on investigating newer and alternative resources for eco-friendly natural products like bacterial pigments for different biomedical and industrial applications. Since the use of synthetic pigments and their by-products in various applications such as cosmetics, food and pharmaceuticals appear to show significant impact on human health as toxic, carcinogenic and teratogenic properties [4], several studies have been undertaken to investigate natural pigment sources from plants and terrestrial bacteria and fungi [8]. Therefore, the present study has focused to investigate the potential applications of various pigment molecules producing bacteria from different marine biota.

Marine bacterial natural characters such as pigments, medicinal properties, and nutrients production like vitamins are dependent on season and geographical conditions. Andaman and Nicobar Islands are located about $1200 \mathrm{~km}$ far from mainland consisting a chain of 836 Islands from North to Southern on longitude $93^{\circ}-94^{\circ}$ East and latitude $6^{\circ}-17^{\circ}$ North. Out of the 836 islands, 38 islands are inhabited, and eight islands are covered under various settlement programmes. These islands have a rich marine biodiversity and erratic weather conditions, which make these islands different from other geographic places. Studies on marine bacterial diversity are a key phenomenon in understanding their biogeography, community assembly and ecological role. In this context, very little is known about pigmented bacterial distribution in marine environment. Studies carried out on pigmented bacteria are very limited in India, and so far, particularly in Andaman studies are scarce [9]. This necessitated the present study to explore pigmented bacterial for food and drug applications.

\section{Material and Methods}

\subsection{Study Area}

Sampling was conducted at seventeen different stations located around the coastal regions of South Andaman Island during low tide. The GPS coordinates (Latitude and longitude) of the seventeen stations are as follows: Corbyn's Cove $\left(11^{\circ} 38^{\prime} 29.78^{\prime \prime} \mathrm{N} \& 92^{\circ} 44^{\prime} 47.99^{\prime \prime} \mathrm{E}\right)$, Burmanallah $\left(11^{\circ} 33^{\prime} 52.24^{\prime \prime} \mathrm{N}\right.$ \& 92 $\left.44^{\prime} 01.51^{\prime \prime} \mathrm{E}\right)$, Kodiyaghat $\left(11^{\circ} 31^{\prime} 47.16^{\prime \prime} \mathrm{N} \& 92^{\circ} 43^{\prime} 25.97^{\prime \prime} \mathrm{E}\right)$, Marina Park $\left(11^{\circ} 40^{\prime} 19.76^{\prime \prime} \mathrm{N}\right.$

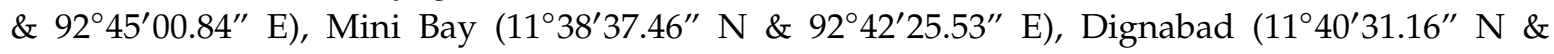
$\left.92^{\circ} 44^{\prime} 40.68^{\prime \prime} \mathrm{E}\right)$, Science Center $\left(11^{\circ} 39^{\prime} 29.32^{\prime \prime} \mathrm{N} \& 92^{\circ} 45^{\prime} 14.40^{\prime \prime} \mathrm{E}\right)$, Wandoor $\left(11^{\circ} 35^{\prime} 36.79^{\prime \prime} \mathrm{N} \&\right.$

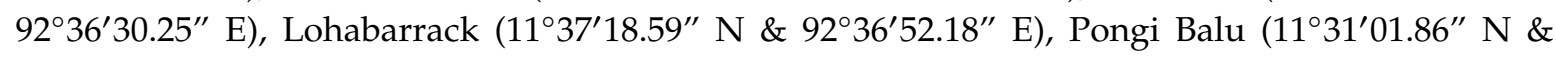
$\left.92^{\circ} 39^{\prime} 13.74^{\prime \prime} \mathrm{E}\right)$, Chidiyatapu $\left(11^{\circ} 29^{\prime} 27.24^{\prime \prime} \mathrm{N} \& 92^{\circ} 42^{\prime} 29.38^{\prime \prime} \mathrm{E}\right)$, Kurma Dera $\left(11^{\circ} 40^{\prime} 00.56^{\prime \prime} \mathrm{N} \&\right.$ $\left.92^{\circ} 35^{\prime} 33.24^{\prime \prime} \mathrm{E}\right)$, Chouldari $\left(11^{\circ} 38^{\prime} 22.97^{\prime \prime} \mathrm{N} \& 92^{\circ} 40^{\prime} 03.93^{\prime \prime} \mathrm{E}\right)$, Manjery $\left(11^{\circ} 32^{\prime} 43.40^{\prime \prime} \mathrm{N} \& 92^{\circ} 38^{\prime} 59.39^{\prime \prime} \mathrm{E}\right)$, 


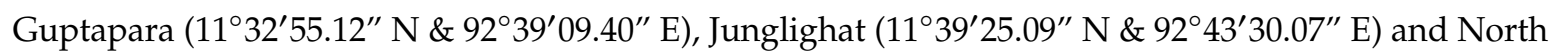
Bay $\left(11^{\circ} 42^{\prime} 30.73^{\prime \prime} \mathrm{N} \& 92^{\circ} 44^{\prime} 44.81^{\prime \prime}\right.$ E) (Figure 1).

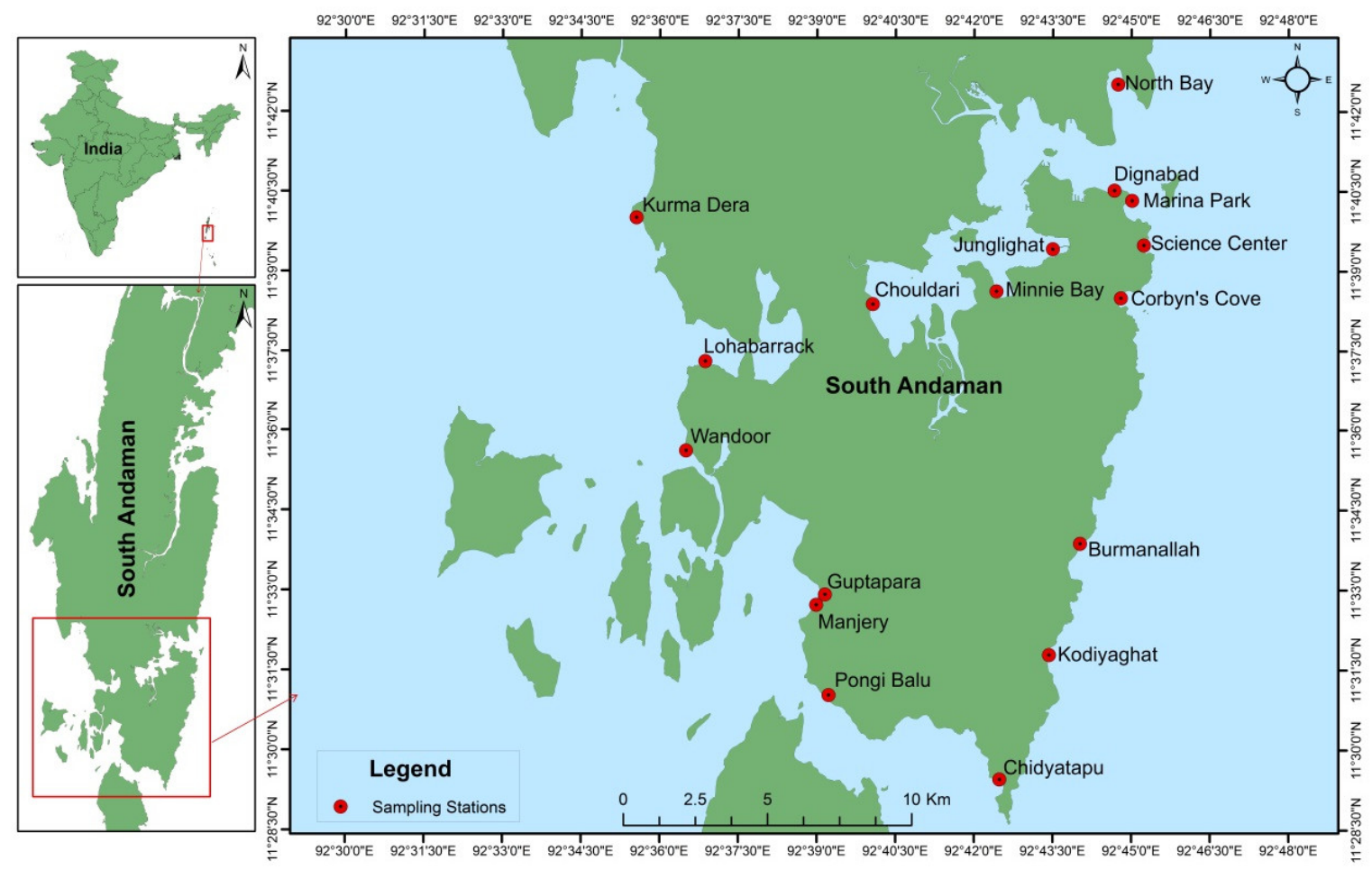

Figure 1. Sampling stations in South Andaman Island.

\subsection{Collection of Samples}

Samples were categorized into two major groups such as biotic and abiotic samples. Biotic samples are comprised of floral and faunal components (Supplementary Table S1). All samples were collected following standard guidelines specified in previous studies [9]. Floral samples including seaweeds, seagrass and mangrove roots were collected using hand pick method following aseptic conditions. Faunal components spanning lower order group of invertebrates to higher order group of vertebrates. Several swab samples were collected from sessile, fragile, rare and dead samples in the field using sterile cotton swabs procured from HiMedia, Mumbai.

Abiotic samples comprised of various materials were as follows: seawater, sediment and Muscovite (common mica). Sea water samples were collected in a sterile water sampler bottle. Sediment samples were collected with a sterile hand corer and transferred it into a sterile sample container. A total of 180 samples including biotic and abiotic samples were collected for investigating the pigmented bacterial presence (Supplementary Table S1). All the samples were collected only once and tested for the occurrence of pigmented bacteria. Samples were placed inside an ice-box in cooled conditions at $4-8^{\circ} \mathrm{C}$ in polystyrene container and transported to laboratory within one hour of sampling for further bacteriological studies.

\subsection{Cultivation and Isolation of Pigmented Bacteria}

Different media such as Marine agar, Nutrient agar, Luminescent agar, Photobacterium agar, Pseudomonas fluorescence agar, Pseudomonas pyocyanin agar, Bacillus agar, Seawater complete agar, Casitose agar, were employed to isolate different pigmented bacteria. All media were prepared using Millipore water and autoclaved in EQUITRON Autoclave (\#7440FA) at $121^{\circ} \mathrm{C}$ for $15 \mathrm{~min}$. Swab samples obtained from different floral and faunal samples were directly swabbed onto different media plates. Sediment and mica sample aliquots were prepared by diluting $1 \mathrm{gm}$ of each sample 
in separate $9 \mathrm{~mL}$ of sterile seawater $(w / v)$ and used for bacteriological analysis [10]. A $100 \mu \mathrm{L}$ of seawater and sediment aliquots were processed using spread plate method [11,12]. Simultaneously, these plates were incubated in bacteriological incubator at $32{ }^{\circ} \mathrm{C}$ and at room temperature for 7 to 10 days. After incubation period, colonies showing pigmentation were picked with sterile toothpicks and sub-cultured by streaking method to obtain pure single isolated colonies.

\subsection{Storage}

Pure single colony pigmented isolates of 14 strains were maintained on agar plates or agar slants at $4{ }^{\circ} \mathrm{C}$ or at room temperature up to $2-3$ months. Glycerol stocks were maintained at $-20{ }^{\circ} \mathrm{C}$ in $5 \mathrm{~mL}$ round bottom polypropylene Cryo Vials $\left(\mathrm{Abdos}^{\mathrm{TM}}\right)$ for longer period and were prepared by inoculating $1.5 \mathrm{~mL}$ of sterile glycerol $(30 \%)$ to $3.5 \mathrm{~mL}$ of strain specific broth for future studies.

\subsection{Molecular Characterization of Pigmented Bacteria}

\subsubsection{Genomic DNA Extraction}

Genomic DNA's of selected pigmented bacterial isolates were extracted using QIAamp DNA Blood Mini Kit, procured from QIAGEN. Initially, lysis of Gram-negative and Gram-positive bacterial cells were achieved by mechanical shearing by sonication for $5 \mathrm{~min}$ and bead homogenizer (FastPrep-24 ${ }^{\mathrm{TM}}$ 5G benchtop homogenizer, MP Biomedicals), followed by enzymatic lysis with proteinase- $\mathrm{K}(20 \mathrm{mg} / \mathrm{mL})$ and lysozyme $(10 \mathrm{mg} / \mathrm{mL})$ respectively for $30 \mathrm{~min}$. Further steps are performed as per the Quick-Start Protocol guidelines of QIAGEN. The isolated DNA was quantified using DeNovix DS-11 + Spectrophotometer by measuring absorptions. Only high-quality DNA with $\mathrm{A}_{260} / \mathrm{A}_{280}$ ratio of 1.8 to 2.0 were used. Intense pigment producing bacterial strains were subjected to 16S rRNA sequence analysis for identification. Further, two potential pigmented bacterial strains are characterized by a combination of molecular techniques such as RAPD \& RFLP, in order to determine the degree of inter- and intraspecific variability for future studies.

\subsubsection{PCR Amplification of $16 \mathrm{~S}$ rRNA Analysis}

PCR amplification of 16S rRNA was carried out in Applied Biosystems Version 2.0 using the bacterial consensus primers 27F [5'-AGA GTT TGA TCC TGG CTC AG-3'] and 1492R [5'-GGT TAC CTT GTT ACG ACT T-3'] universal forward and reverse 16S rRNA primers [13]. The PCR of the genomic DNA isolate were conducted in a final volume of $25 \mu \mathrm{L}$. The reaction mixture contained $10 \times$ PCR buffer, $25 \mathrm{mM} \mathrm{MgCl}_{2}, 10 \mu \mathrm{M}$ DNTP's, $1 \mathrm{U}$ of Taq DNA polymerase, 10 pmol of each forward and reverse oligonucleotide primers and approximately $20 \mathrm{ng}$ of genomic DNA. The amplification profile consisted of an initial denaturation at $94{ }^{\circ} \mathrm{C}$ for $3 \mathrm{~min}$, followed by 35 cycles at $94{ }^{\circ} \mathrm{C}$ for 30 sonds, $52{ }^{\circ} \mathrm{C}$ for $1 \mathrm{~min}$ and $72{ }^{\circ} \mathrm{C}$ for $1 \mathrm{~min}$. This was followed by a final extension step of $72{ }^{\circ} \mathrm{C}$ for $5 \mathrm{~min}$. The samples were held at $4{ }^{\circ} \mathrm{C}$ until further sequence analysis.

\subsubsection{RAPD-PCR Analysis}

Two red pigment strains BSE6.1 and S2.1 were subjected to RAPD analysis with twenty different primers, which are procured from Eurofins (Bangalore, India). Chromosomal DNA of strains BSE6 \& S2 have been used to generate the discrimination profile for identifying these strains rapidly using this analysis. The twenty primers used for RAPD analysis were as follows: OPA-07 GAAACGGGTG, OPA-12 TCGGCGATAG, OPB-01 GTTTCGCTCC, OPB-15 GGAGGGTGTT, OPC-05 GATGACCGCC, OPD-10 GGTCTACACC, OPE-11 GAGTCTCAGG, OPF-05 CCGAATTCCC, OPJ-01 CCCGGCATAA, OPJ-12 GTCCCGTGGT, OPR-05 GACCTAGTGG, OPR-12 ACAGGTGCGT, OPU-06 ACCTTTGCGG, OPU-13 GGCTGGTTCC, OPU-17 ACCTGGGGAG, OPV-06 ACGCCCAGGT, OPW-10 TCGCATCCCT, OPX-08 CAGGGGTGGA, OPX-13 ACGGGAGCAA, and OPZ-19 GTGCGAGCAA.

The final reaction volume of $25 \mu \mathrm{L}$ was used to perform RAPD-PCR amplification, following the optimized conditions of: $94{ }^{\circ} \mathrm{C}$ for $5 \mathrm{~min}, 35$ cycles of $94{ }^{\circ} \mathrm{C}$ for $30 \mathrm{~s}, 35^{\circ} \mathrm{C}$ for $30 \mathrm{~s}, 7{ }^{\circ} \mathrm{C}$ for $3 \mathrm{~min}$, 
and final extension at $72{ }^{\circ} \mathrm{C}$ for $7 \mathrm{~min}$. Then PCR products were resolved in $1.2 \%$ TAE agarose gels at $80 \mathrm{~V}$ for $40 \mathrm{~min}$ in electrophoresis unit. The molecular markers of $100 \mathrm{bp}$ and $1 \mathrm{~Kb}$ DNA ladders were used as a size markers. Subsequently, the different polymorphic DNA banding patterns observed were recorded.

\subsubsection{RFLP Analysis of Amplified 16S rRNA}

Four different restriction enzymes such as AluI (BioLabs, New England), HindIII, BamHI and EcoRI (HiMedia, Mumbai, India) were used to generate species specific ARDRA banding patterns. Approximately, $7 \mu \mathrm{L}$ of PCR amplified 16S rRNA products of BSE6.1 and S2.1 were digested with $1 \mathrm{U}$ of each restriction enzyme following manufactures guidelines (HiMedia, Mumbai). The reaction mixture in a total volume of $25 \mu \mathrm{L}$ containing $7 \mu \mathrm{L}$ of amplified DNA, $2 \mu \mathrm{L}$ of restriction enzyme, $5 \mu \mathrm{L}$ of $10 \times$ reaction buffer and $11 \mu \mathrm{L}$ of molecular grade water (HiMeida). The reaction mixtures were incubated at $37^{\circ} \mathrm{C}$ for 15 to 30 min or left overnight, followed by inactivation of enzymes by heating at $65{ }^{\circ} \mathrm{C}$ for $15 \mathrm{~min}$. Then, the reaction products were analysed by $3 \%(w / v)$ agarose gel electrophoresis in TAE buffer containing $3 \mu \mathrm{L}$ of ethidium bromide in $30 \mathrm{~mL}$ gel.

\subsubsection{Sequencing and Phylogenetic Analysis}

All the isolates were sequenced with an automatic sequencer Applied bio system, Foster City, USA. Raw sequences alignment and quality were checked with MEGA 6 software [14]. The Black box chimera check (B2C2) software was used to check chimera formations [15]. The partial 16S rRNA gene sequences of these isolated strains were compared with those in the public databases including GenBank, DDBJ, EMBL, ENA, EzBioCloud, LeBibi database, Ribosomal Database (RDP), CAMERA 2.0 Portal and EzTaxon-e database to search for the nearest phylogenetic neighbour. Species level identification was determined by the $16 \mathrm{~S}$ rRNA sequence similarity of $99 \%$ with that of the prototype sequence available in GenBank. Sequence alignment and comparison was performed using the multiple sequence alignment program ClustalW [16]. Sequence similarities and nucleotide gaps were also calculated and edited using BIOEDIT software. Neighbour-joining method was chosen to construct and to calculate the evolutionary distance of the phylogenetic tree using MEGA6 software [17]. Bootstrap analysis was performed by applying 1000 resamplings to evaluate the topology of neighbour joining tree [18].

\subsubsection{Nucleotide Sequence Accession Numbers}

Nucleotide sequences of $16 \mathrm{~S}$ rRNA gene were deposited in the NCBI GenBank under assigned accession numbers.

\subsection{Extraction and Preparation of Crude Pigmented Compounds}

Pure pigmented bacterial strains were cultured in $100 \mathrm{~mL}$ of respective broth as mentioned above for 5-7 days under shaking with $200 \mathrm{rpm}$ (ORBITEK-Scigenics Biotech) at $28{ }^{\circ} \mathrm{C}$ in $250 \mathrm{~mL}$ Erlenmeyer flasks $[9,19]$. This was followed by centrifugation at 10,000 rpm for $10 \mathrm{~min}$ (SIGMA 3-30KS). The raffinate and cell pellets of pigmented bacterial strains were extracted with an equal volume of methanol until the pellet was colourless. The organic phases were collected using separating funnel and transferred into separate glass bottles for rotary evaporation. Solvent from the extracts was removed under reduced pressure at $40{ }^{\circ} \mathrm{C}$ by rotatory evaporation (BÜCHI Rotavapor R-205, BÜCHI Vacuum controller V-800 \& BÜCHI Chiller B-740). The crude products thus obtained were redissolved in $1 \mathrm{~mL}$ of the same solvent for further applications. 


\subsection{Antibacterial Properties of Pigment Extracts}

\subsubsection{Human Bacterial Pathogens}

Human bacterial pathogenic culture in lyophilized powder form was purchased from Microbial Type Culture Collection and Gene Bank (MTCC), CSIR-Institute of Microbial Technology, Chandigarh, India. The Staphylococcus aureus subsp. aureus MTCC1430 was obtained and retrieved on specified media given in the guidelines of MTCC. This pathogen was chosen due to its pathogenicity, causing a range of minor skin infections to life-threatening diseases.

\subsubsection{Preparation of Human Pathogenic Bacterial Inoculums}

Stringent aseptic conditions were adopted for preparation of aforementioned pathogenic bacterial inoculums. A loop full of each human pathogenic bacterial culture was inoculated into separate $5 \mathrm{~mL}$ glass tubes containing enriched broth medium, i.e., Muller Hinton broth. These inoculated culture tubes were incubated at $35^{\circ} \mathrm{C}$ for overnight. Broth cultures with an optical density of $\mathrm{OD}_{600}=1$ were used as inoculum suspensions for antibacterial assay.

\subsubsection{Antibacterial Assays}

Antibacterial activity assay was performed according to Kirby-Bauer well diffusion and disc diffusion method [20]. Using sterile cotton swabs, overnight grown inoculum suspensions of pathogenic bacteria that gives a lawn density of approximately $10^{5}$ to $10^{8} \mathrm{CFU} / \mathrm{mL}$ were swabbed onto the surface of Mueller-Hinton agar plates. Lids of petri dishes were left ajar for 2 to 5 min to remove excess surface moisture. Wells were made on media plates using cork borers and impregnated with $100 \mu \mathrm{L}$ of crude extracts. Sterile disks treated with equal volume of respective solvents of each extract were used as negative control. After complete diffusion of extractions into media, plates were incubated at $35^{\circ} \mathrm{C}$ for $24 \mathrm{~h}$. The inhibition zones around the disc were measured including disc diameter $(6 \mathrm{~mm})$.

2.7.4. Minimum Inhibitory Concentration (MIC) and Minimum Bactericidal Concentration (MBC) Assays

MIC and MBC were defined as the lowest concentration of pigment compounds which inhibited the visible growth of a microorganism after overnight incubation with specific concentration of pigment compounds. Tube dilution method was carried out using aseptic conditions as per the standard protocols [21,22]. Sterile test tubes were numbered 1 to 7 . The dried pigment compounds of BSE6.1 and S2.1 with concentrations of $400 \mu \mathrm{g} / \mathrm{mL}$ and $300 \mu \mathrm{g} / \mathrm{mL}$ respectively were diluted in first test tube containing $2 \mathrm{~mL}$ of Muller Hinton broth (MHB). And, to all other test tubes $1 \mathrm{~mL}$ of MHB was added. From the 1st test tube $1 \mathrm{~mL}$ was transferred to the sond tube and the same was followed till fifth tube (concentrations are given in the figures). From fifth test tube $1 \mathrm{~mL}$ was discarded. To all these tubes $100 \mu \mathrm{L}$ of multiple infections causing pathogen S. aureus subsp. aureus MTCC1430 culture with OD value 1 was inoculated and vortexed gently. Sixth tube containing MHB serves as negative control and seventh tube with $S$. aureus inoculum in MHB serves as positive control. All these tubes were incubated at $35^{\circ} \mathrm{C}$ for $24 \mathrm{~h}$. The lowest concentration that inhibited the growth of $S$. aureus completely was defined as MIC. MBC was measured by transferring $100 \mu \mathrm{L}$ of culture suspensions from each tube used in MIC assay onto Muller Hinton agar and incubated at $35^{\circ} \mathrm{C}$ for $24 \mathrm{~h}$ or longer. The plates that have not formed any growth was considered as MBC.

\subsection{Food Colorant and Staining Applications of Pigments}

Crude concentrated pigment extracts obtained from potential pigmented strains were investigated for food colorant and staining applications. For food colorant application, agar jellies were prepared by dissolving 5\% agar in $100 \mathrm{~mL}$ distilled water, heated and melted until agar residues disappear. At $45^{\circ} \mathrm{C}$, different pigment extracts with concentration of $500 \mu \mathrm{g}$ were dissolved separately in melted 
agar solution and poured into jelly making plate. After complete solidification, jellies were removed and kept at $4{ }^{\circ} \mathrm{C}$ for few months to see the long lasting capability of pigment.

For staining application, Tridax procumbens stem was used for testing the staining capacity of different pigment extracts. Transverse stion of T. procumbens stem were dipped for two min and observed under microscope to see any cell specific (epidermis, xylem, phloem, parenchyma) staining is occurred.

\subsection{Statistical Analysis}

All experiments were performed in triplicates for error analysis and the values derived from triplicates were expressed as means \pm standard error and presented in each graph.

\section{Characterization of the Pigment}

\subsection{Thin Layer Chromatography Analysis (TLC)}

Compound characterization was only performed to red pigment strains BSE6.1 and S2.1 due to their effective antimicrobial activities. TLC was performed on silica gel coated aluminium sheets (60 F254, Merck) procured from Merck. The crude extract was loaded on the line drawn on silica-coated plates using a fine capillary tube $(2-5 \mu \mathrm{L})$ and immersed in the solvent system just below the sample loaded line. Different solvent systems were tested to obtain the best separation of compounds. The best optimized solvent system used for separating red pigment compound of strain BSE6.1 and S2.1 were methanol, hexane and dichloromethane at the ratio of 1:3:6. The plates were removed after the solvent reaches the $3 / 4$ th of the plate, dried, and examined to count the number of distinct pigment bands separated under normal light, and fluorescent spots in a UV-chamber at $366 \mathrm{~nm}$. Subsequently, $\mathrm{R} f$ (retention factor) values were calculated using the below formula and compared with the $\mathrm{R} f$ values reported in previous studies. The TLC-pure compounds of BSE6.1 and S2.1 were further subjected to HPLC, UV-Visible spectroscopy, infrared spectroscopy (FT-IR), GC-MS and proton NMR. Analytical part of these samples using HPLC, FT-IR, GC-MS and NMR were carried out at Indian Institute of Chemical Technology, Hyderabad.

$$
R f=\frac{\text { Distance travelled by the compound }}{\text { Distance travelled by the solvent front }}
$$

\subsection{High Performance Liquid Chromatography Analysis (HPLC)}

HPLC has emerged as the most versatile and robust technique for isolation and identification of metabolites like pigments. Distinct bands observed in TLC were separated by scrapping with fine pointed surgical blade and dissolved in same solvent and vortexed well until the silica gel becomes colourless. The pigmented solvent was separated carefully from silica gel and centrifuged at 10,000 rpm for $7 \mathrm{~min}$ and pipetted out into a new tube and used for HPLC.

\subsection{UV-Visible Spectrophotometry}

Purified red pigment compounds of strains BSE6.1 and S2.1 were dissolved in methanol and absorbance was scanned using spectrophotometer (PerkinElmer UV/VIS spectrophotometer Lambda25) between 200 and $750 \mathrm{~nm}$ to obtain the maximum absorption wavelength associated with these pigments. Prior to scanning, instrument was calibrated with ethanol as blank.

\subsection{Fourier-Transform Infrared Spectroscopy (FT-IR)}

Infrared spectra of red pigments in ethanol solvents were collected by placing the pigments samples on separate KBr pellets. Absorption spectra were collected in the range of 500 to $4000 \mathrm{~cm}^{-1}$ using Thermo Nicolet Nexus 670 Spectrometer with DTGS-KB detector and resolution $4 \mathrm{~cm}^{-1}$. The IR spectra were identified by using FT-IR spectra library [23]. 


\subsection{Gas Chromatography and Mass Spectrometry (GC-MS) Analysis}

GC-MS was performed to identify the major and minor compounds present in purified red pigments. The following samples BSE6.1 and S2.1 were analysed by GC-MS technique on Agilent6890 Series GC-MS, using HP-5MS $30 \mathrm{~m} \times 0.25 \mathrm{~mm} \times 0.25 \mu \mathrm{m}$ column with $1.2 \mathrm{~mL}$ flow rate. Different compounds detected in the spectra were identified using NIST05a.L library.

\subsection{Proton NMR Spectroscopy Analysis}

Proton $\left({ }^{1} \mathrm{H}\right)$ NMR spectroscopy was used to detect the magnetic fields around the atomic nuclei. The proton spectral data of red pigments of BSE6.1 and S2.1 were generated in deuterated chloroform $\left(\mathrm{CDCl}_{3}\right)$ solution at $400 \mathrm{MHz}$, using a Bruker Avance-400 solid NMR spectrometer.

\section{Results and Discussion}

\subsection{Isolation of Marine Pigmented Bacteria}

Significantly in all the examined samples, pigmented bacteria were more abundant in sediment and invertebrate samples (Figure 2). Although different pigmented isolates including yellow, orange, black, greenish, brown and red were isolated (Figure 3, Supplementary Material, Figures S1-S3), more frequently and abundantly orange, red, brown and green were observed in this study (Figures 4 and 5). Among all the sampling stations, Burmanallah revealed the potential source of pigmented bacterial diversity (Figure 3). Totally, viable pigmented bacteria account for 1.4 to $14 \%$, viable but non-culturable marine pigmented bacteria (VBNC-MPB) for 90 to $97 \%$, pigmentation lost cultures with $0.7 \%-1.6 \%$ and diffusible pigment producing bacteria are $1 \%$. Most of the pigmented bacterial isolates have grown on agar media after 10-20 days of incubation.

Apparently, most of the isolates found to be uncultivable upon first streaking, and some after longer period or even on first isolation as is the frequently observed case with red pigment isolates (Supplementary Figures S4 and S5). Also, several potential agar degrading bacteria were observed along with the pigmented bacterial isolates, hence sometimes the plates become liquid (Supplementary Figure S6). Principal component analysis also indicated the dominance of orange, red, green, and brown pigmented bacterial isolates in South Andaman Island (Figure 6).

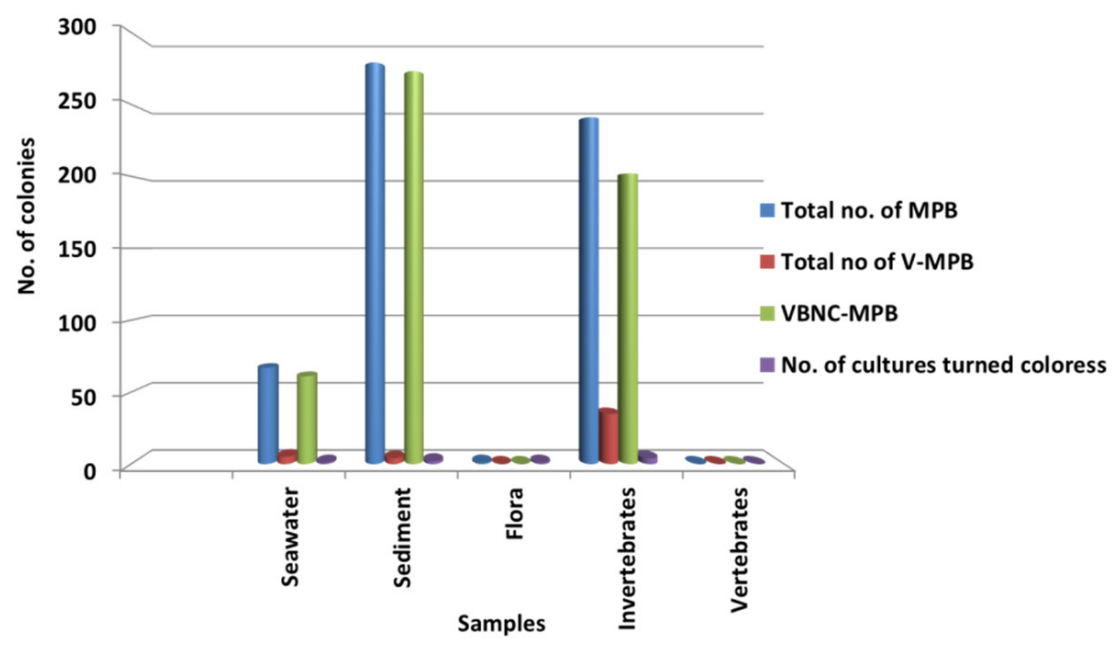

Figure 2. Dominance of pigmented bacteria in different sample groups. 


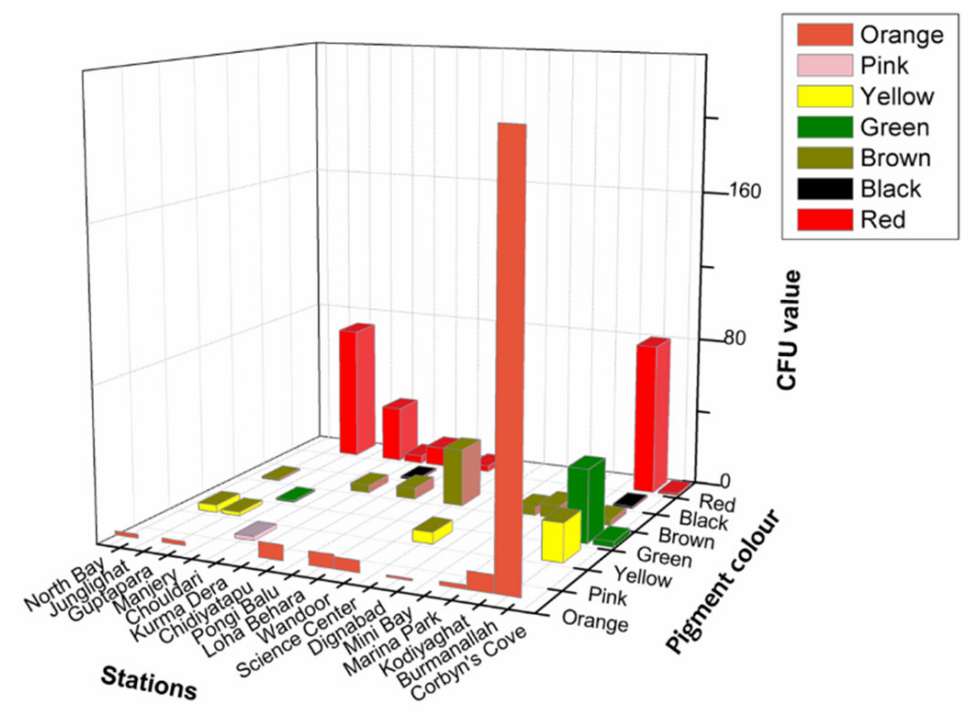

Figure 3. 3D plot showing abundance of type of pigmented bacteria from different stations.
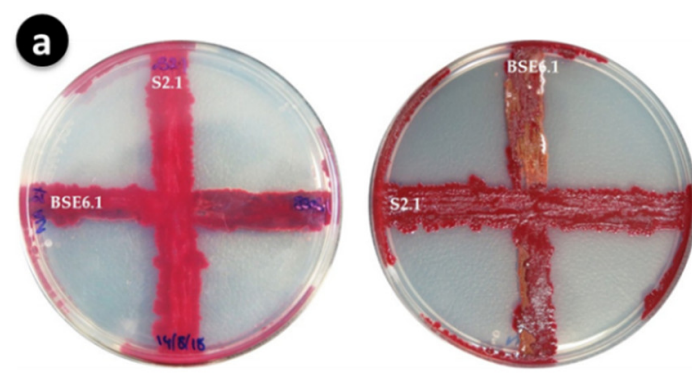

b

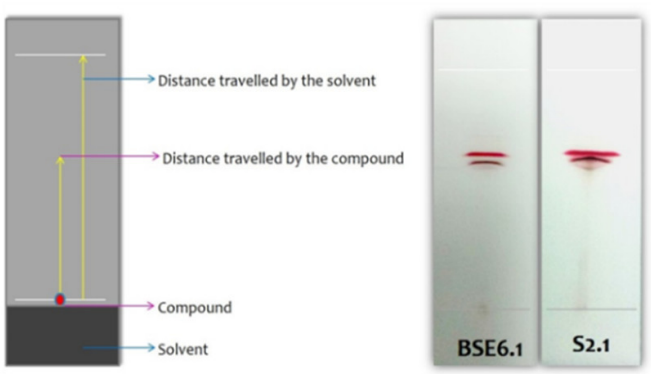

(C)

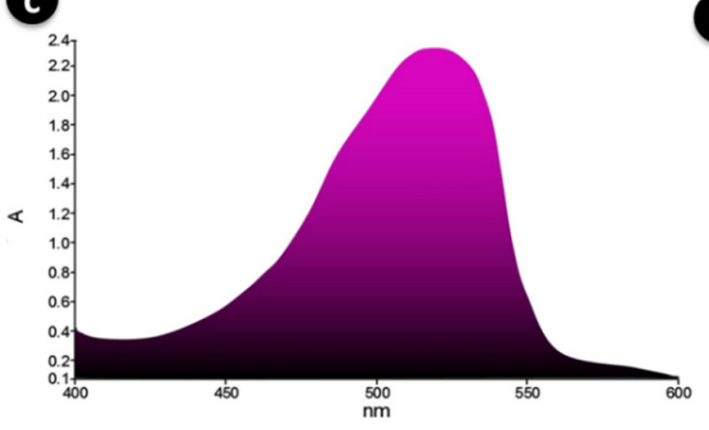

d

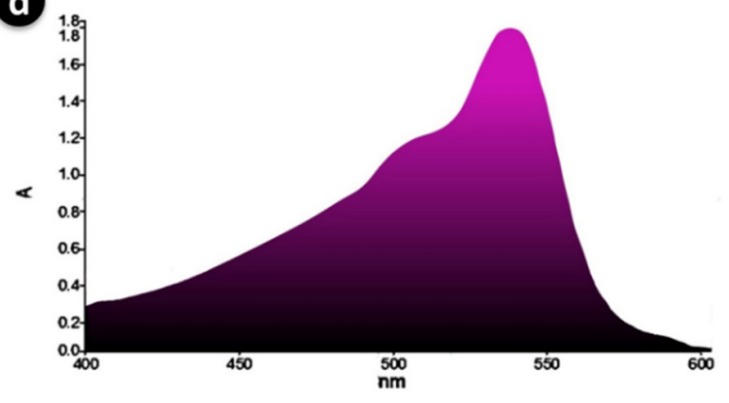

Figure 4. Cross streaking of strains BSE6.1 and S2.1 showed no positive antagonistic activity (a); Separation of main red pigment fractions of BSE6.1 \& S2.1 by TLC (b); Maximum absorption wavelengths of $528 \mathrm{~nm}$ for strain BSE6 (c) and 538 for strain S2.1 (d). 

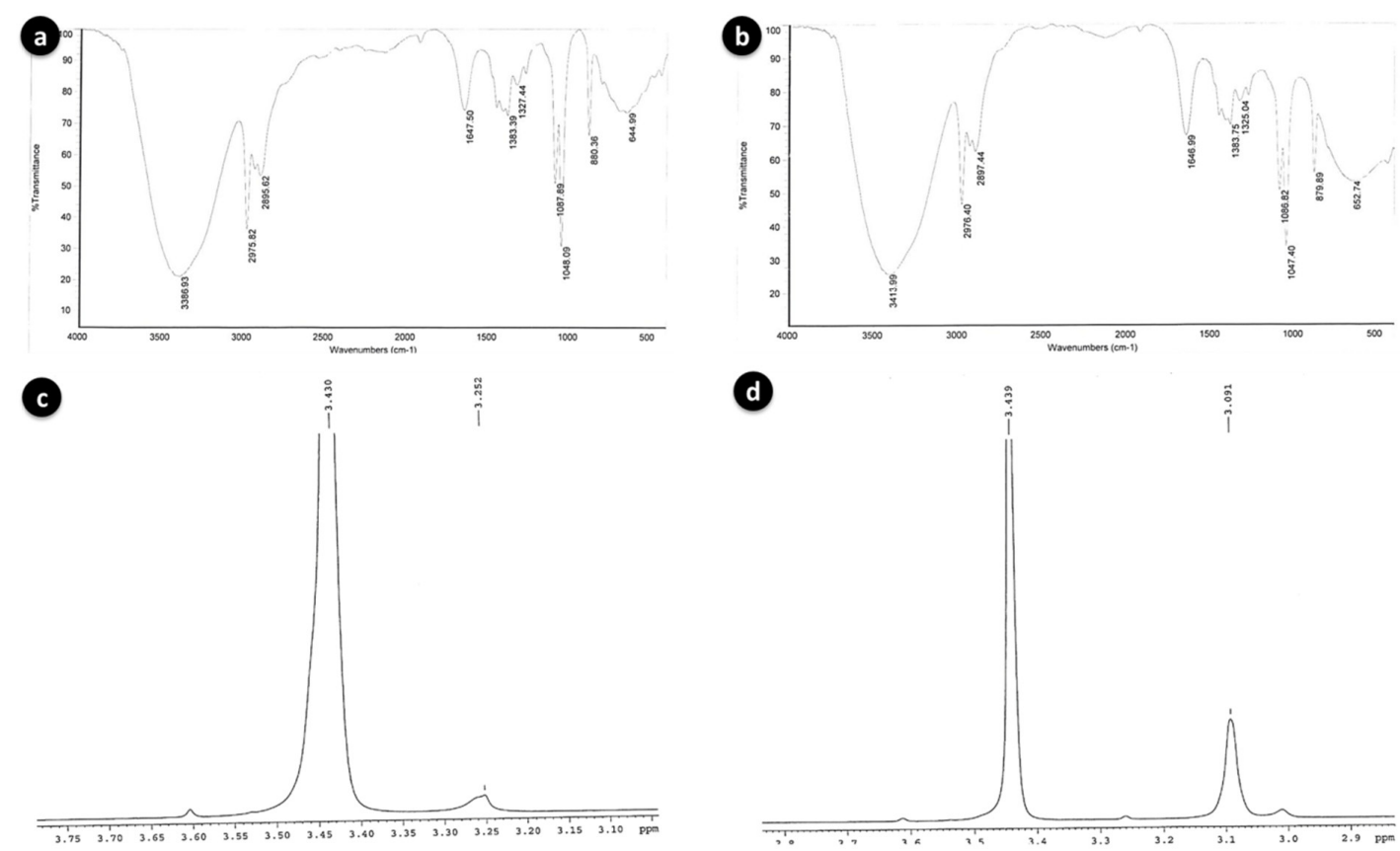

Figure 5. FT-IR spectra of BSE6.1 (a) and S2.1 (b); Proton NMR spectra of BSE6.1 (c) and S2.1 (d).

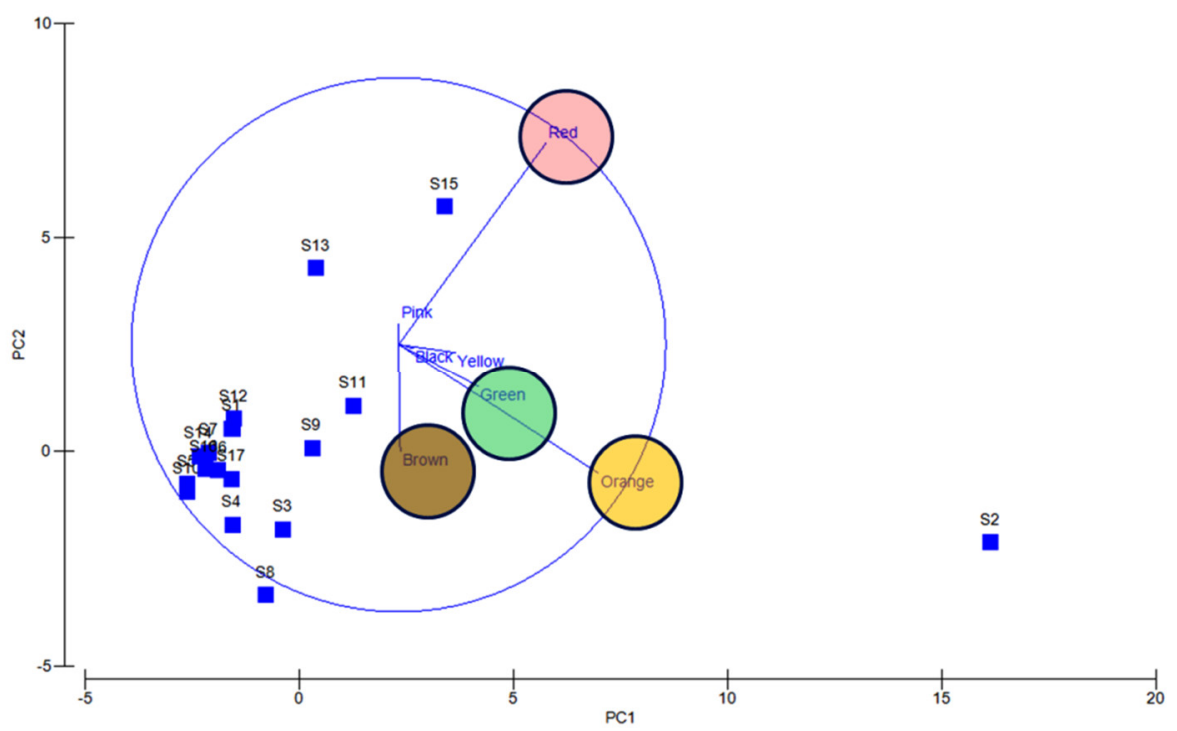

Figure 6. PCA analysis reveals orange, red, green and brown colored bacterial dominance. Blue lines and circles indicate the dominance and distribution patterns of pigment bacteria at different stations.

Strain BSE6.1 showed temperature induced red pigment (Figure 7a,c). Strain S2.1 displayed pink colour in nutrient broth supplemented with calcium $\left(\mathrm{CaCO}_{3}\right)$. Both these strains showed a dark red pigment at $\mathrm{pH} 1$ and yellow pigmentation at $\mathrm{pH} 12$ (Figure 7b). Newly formed colonies of strain S2.1 shows a pink colour, then becomes blood red, and later brownish red after few months. Surfaces of this strain colonies also display metallic greenish and golden yellow sheen coating. Whereas, strain BSE6.1 produces pink color in Minimal broth with $2 \% \mathrm{NaCl}$, and red pigment production in all other media. It also produces tiny white colored spores on both broth and agar media after 7 or 10 days of incubation. 


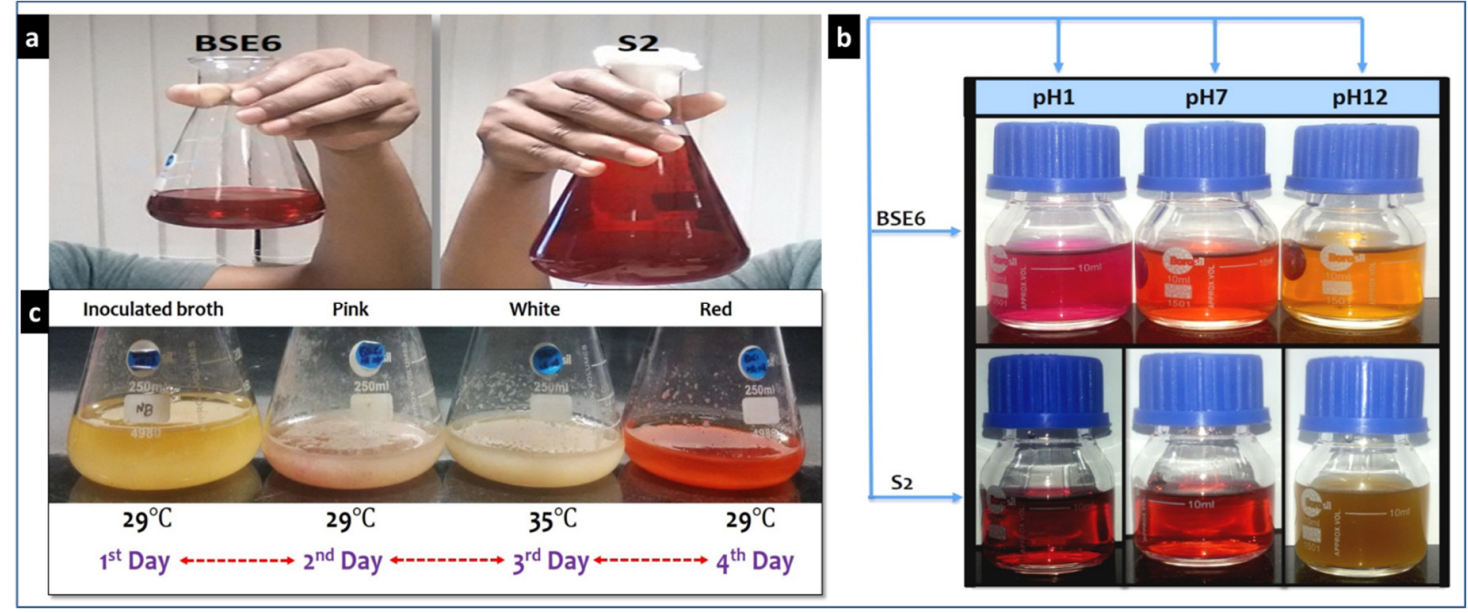

Figure 7. Red pigment extracts of strains BSE6 \& S2.1 (a), and their pigment color variation at different pH's (b); Heat stimulated pigmentation in strain BSE6.1 (c).

\subsection{Antibacterial Activity of the Pigment}

Out of fourteen pigment bacterial strains tested, two red pigment strains displayed effective antibacterial application against all the tested pathogens, including Enterococcus faecalis MTCC9845, Escherichia coli MTCC730, Klebsiella pneumoniae subsp. pneumoniae MTCC109, Salmonella enterica MTCC1165, Salmonella enterica ser. typhi MTCC733, Salmonella enterica typhimurium MTCC98, Staphylococcus aureus subsp. aureus MTCC1430 and Streptococcus mutans MTCC890. MIC and MBC analysis of both pigment extracts obtained from strain S2.1 and BSE6.1 displayed complete inhibition of $S$. aureus at the ranges between 150 to $400 \mu \mathrm{g} / \mathrm{mL}$ concentrations, respectively (Figure 8). Prodigiosin extracts (with concentrations of 50 to $400 \mu \mathrm{g} / \mathrm{mL}$ ) obtained from various marine bacteria are reportedly displayed effective antibacterial against different pathogenic bacteria [5]. The inhibition zones (20 to $28 \mathrm{~mm}$ ) observed in this study are greater than the previous studies $[5,24]$. Thus, strains S2.1 and BSE6.1 are offering great demand for drug development.
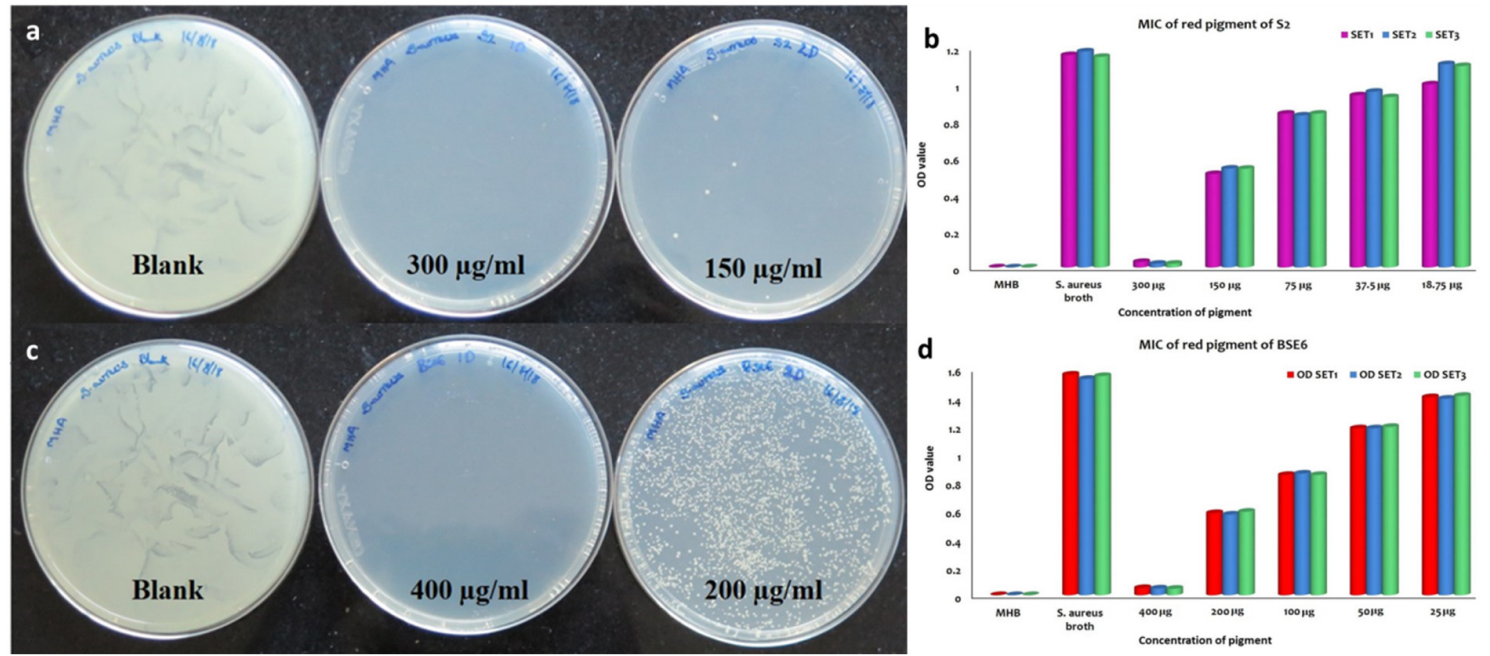

Figure 8. MBC and MIC of S2.1 extracts against S. aureus (a,b). MBC and MIC of BSE6.1 extracts against S. aureus $(\mathbf{c}, \mathbf{d})$.

\subsection{Application of Pigments as Strainers and Food Colorants}

The application of food colorant and staining properties of different pigmented bacterial extracts showed potential food colorant and staining properties (Figure 9). For the first time, this study 
demonstrated the natural staining of stem stions of Tridax procumbens. Agar jellies colored with pigments have lasted up to 3 months with intact pigment, indicating that these pigments can be used as food grade pigments. Staining of T. procumbens stem also displayed three strains BSE6.1, CO8 and SQ2.3 have strong ability to stain epidermis and parenchyma cells. Therefore, these pigments can be used for staining applications in laboratories and education centres.

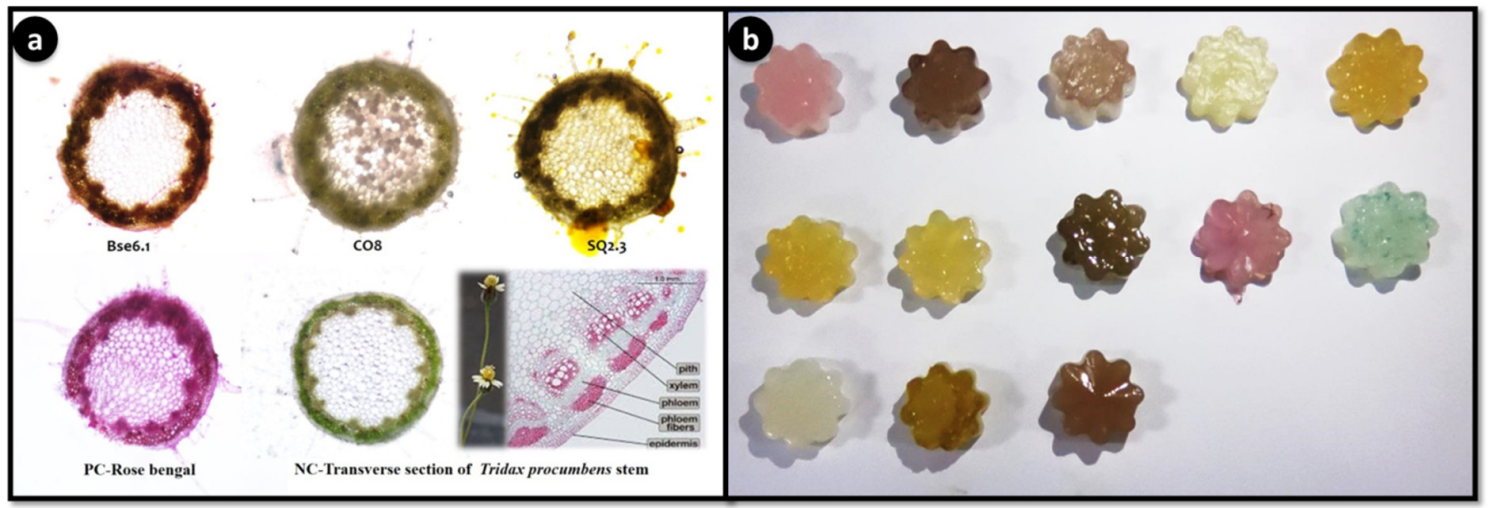

Figure 9. Staining application of potential pigment strains. Transverse stions of Tridax procumbens stem. PC: positive control-Rose bengal; NC: negative control-Tridax stem (a); Food colorant application as agar jellies prepared using extractions of different pigment bacterial strains (pink color jellies represent strain BSE6.1. \& S2.1) (b).

\subsection{Purification and Identification of the Pigment}

Both strains were initially cross streaked to investigate the antagonism between each other. However, antagonism was not observed between these two strains (Figure 4a). Crude pigments were purified on TLC and observed two distinct red pigment bands with $\mathrm{R} f$ values of 0.6 for both strains (Figure 4b). UV-Visible spectroscopic analysis with purified pigment compounds of BSE6.1 and S2.1 revealed maximum absorption spectra at $528 \mathrm{~nm}$ and $538 \mathrm{~nm}$, respectively (Figure 4c,d). Several researchers reported that prodigiosin is a primary pigment in Serratia sp. and has the maximum absorbance at $535 \mathrm{~nm}$ [25].

Further analysis with HP-LC, GC-MS, FT-IR and proton NMR revealed highly similar chemical properties among these two strains. The major red pigmented compound constituents were identified by HPLC at the indicated retention times of $8.09 \mathrm{~min}(\mathrm{~m} / \mathrm{z} 324$, prodigiosin) for strain BSE6.1 and $9.72 \mathrm{~min}$ ( $\mathrm{m} / \mathrm{z} 338$, 2-methyl-3-hexyl prodiginine) for strain S2.1. These particular retention peaks were separated and FT-IR, NMR analysis were conducted. Major chemical compounds responsible for red pigment production in both red pigmented strains BSE6.1 and S2.1 were also identified as prodiginine constituents in GC-MS. Mass spectrometry analysis revealed presence of 2-methyl-3-propyl prodiginine compound $(m / z 296)$ at 6.36 RT and 24.50 RT in strain S2.1 and in strain BSE6.1, streptophenazine, a yellow compound ( $m / z$ 496) and 2-methyl-3-butyl prodiginine or 2-methyl-3-propyl prodiginine, a prodiginine components of red pigment compound ( $m / z 310$ or $m / z 296)$ were detected at 35.27 RT and 17.18 or 18.61 respectively. These spectra are similar to the published prodiginine constituents [24]. FTIR and NMR results are also in accordance with GC-MS library with slight variation.

The broad stretching IR peaks similar to prodigiosin compound were detected at frequency range $3386-644 \mathrm{~cm}^{-1}$ in both the red pigment extracts of S2.1 and BSE6.1. Weak absorption at 2500-1700 $\mathrm{cm}^{-1}$ was detected in both bacterial strains. The prodiginine compound spectra observed for strain BSE6.1 was 3386, 2975, 1647, and 1087, and for BSE6.1, 3413, 2976, 1646, and 1086 (Figure 5a,b). These broad IR peaks are in accordance to the prodigiosin peaks 3105, 2928, 1644, 1602 and 1125 reported in a previous study [26]. Song et al. (2006) reported that Serratia sp. KH95 was dominated by strong bands at $2928 \mathrm{~cm}^{-1}$ (aromatic $\mathrm{CH}$ ) and $1602 \mathrm{~cm}^{-1}$ (aromatic $\mathrm{C}=\mathrm{C}$ ) [27]. The pigment was identified to be prodigiosin on the basis of spectroscopic data of ${ }^{1} \mathrm{H}-\mathrm{NMR}\left(400 \mathrm{MHz}, \mathrm{CDCl}_{3}, \delta\right)$. The ${ }^{1} \mathrm{H}-\mathrm{NMR}$ spectra of 
red pigment extracted from Zooshikella sp. strain S2.1 and Streptomyces sp. strain BSE6.1 are comprised of almost similar functional groups and characteristic chemical shifts (ppm) with consistent functional groups. Two major spectral signals were detected at ppm 3.430 and between 3.091 to 3.252 (Figure 5c,d); confirming the presence of red pigmented prodiginine chemical components as reported earlier [26]. Prodigiosin compounds give a typical signals of NMR protons on the three heterocyclic structures between 6-7.3 ppm for Z. ganghwensis, Pseudoalteromonas sp., and Pseudoalteromonas rubra [26,28,29]. Song et al. (2006) reported that, a chemical shift of the methoxy group in prodigiosin exhibited peak at $4.04 \mathrm{ppm}$ as singlet in Serratia sp. KH-95 [27]. However, slight chemical shifts observed in the pigment compound of both strains S2.1 and BSE6.1 indicating a different prodigiosin chemical component.

\subsection{Identification of the Potent Strains S2.1 and BSE6.1}

PCR amplification was successful and amplified a 1500 bp size of 16S rRNA gene (Figure 10a). Selected pigmented bacterial strains were identified up to genus or species level (Table 1). Sequence analysis of the 16S rRNA gene revealed that strain S2.1 and BSE6.1 represents a novel lineage within the family Hahellaceae and Streptomycetaceae respectively. Strain S2.1 was Gram-negative, intensive blood red pigmented, that showed the sequence similarity of $99.77 \%$ with the closely related species of Zooshikella marina strain JC $333^{\mathrm{T}}$.

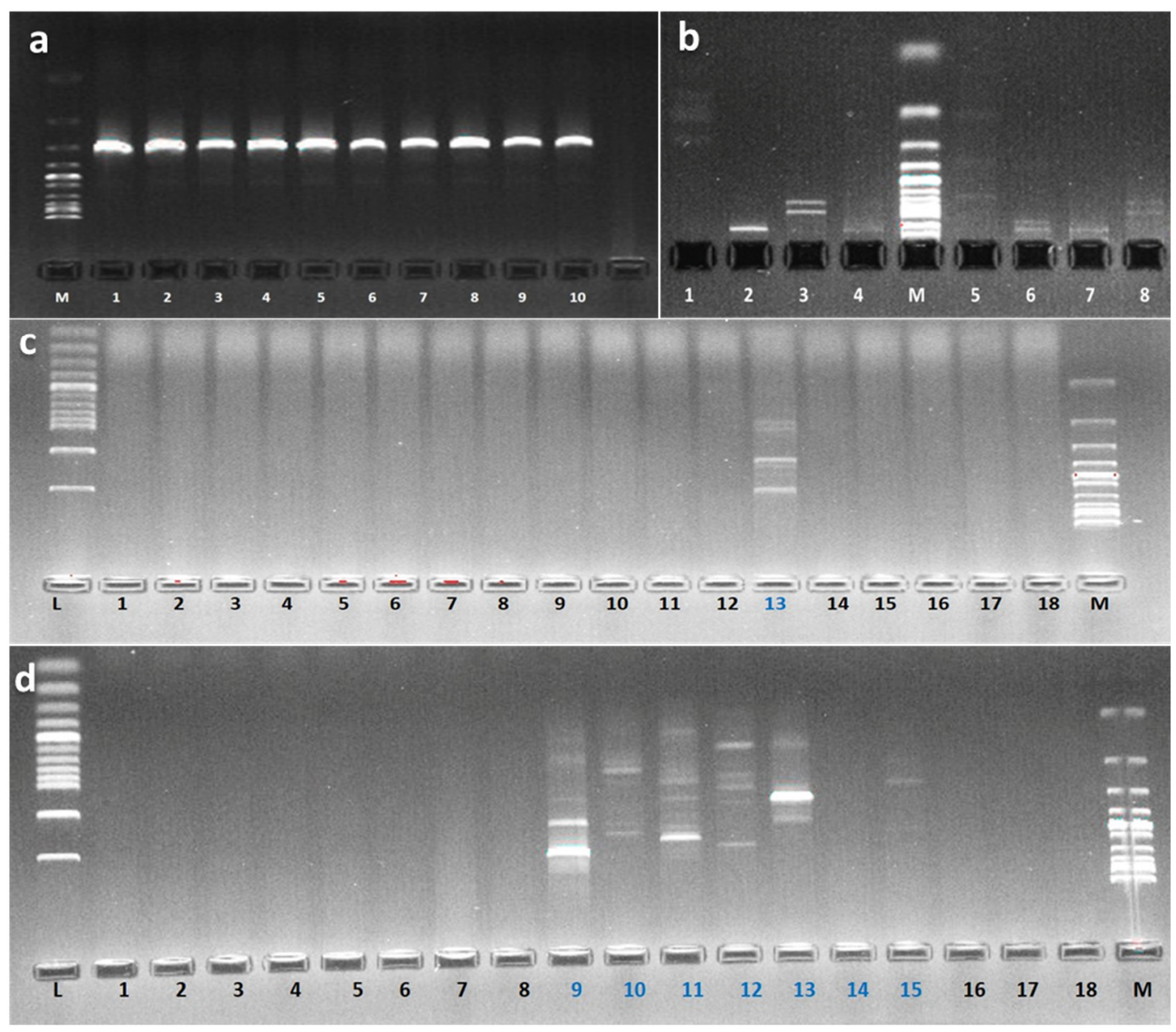

Figure 10. PCR amplified products of $16 \mathrm{~S}$ rRNA. M: Ladder $1 \mathrm{~Kb}$; Numbers: 1, (a); RFLP banding patterns of S2.1 (1 to 4) and BSE6.1 (5 to 8) digested with endonucleases AluI, HindIII, BamHI and EcoRI. M: Ladder $100 \mathrm{bp}$ (b); Agarose gel electrophoresis of amplified DNA products of BSE6.1 1 digested with different RAPD primers. L: Ladder 100 bp \& M: Ladder $1 \mathrm{~Kb}$ (c); Agarose gel electrophoresis of amplified DNA products of S2.1 digested with different RAPD primers. L: Ladder 100 bp \& M: Ladder $1 \mathrm{~Kb}(\mathbf{d})$. 
Table 1. Identification of pigmented bacterial strains using 16s rDNA sequence.

\begin{tabular}{|c|c|c|c|c|c|}
\hline S.No & $\begin{array}{l}\text { Pigmented } \\
\text { Bacterial } \\
\text { Strain }\end{array}$ & Isolation Source & $\begin{array}{l}\text { GenBank } \\
\text { Accession } \\
\text { Number }\end{array}$ & $\begin{array}{l}\text { Sequence } \\
\text { Similarity \% }\end{array}$ & Identified as \\
\hline 1. & SW1 & Seawater & MK680109 & 99.62 & $\begin{array}{l}\text { Pseudoalteromonas } \\
\text { peptidolytica }\end{array}$ \\
\hline 2. & SW2 & Seawater & MK680110 & 99.02 & $\begin{array}{l}\text { Pseudoalteromonas } \\
\text { peptidolytica }\end{array}$ \\
\hline 3. & SW4 & Seawater & MK680111 & 99.27 & Gordonia terrae \\
\hline 4. & $\mathrm{CO} 2$ & Conus miles & ND & & ND \\
\hline 5. & SQ2.3 & Juvenile squid & ND & & ND \\
\hline 6. & PC3 & & MK680107 & 96.66 & Nitratireductor basaltis \\
\hline 7. & NBE2 & $\begin{array}{l}\text { Unidentified } \\
\text { nudibranch egg mass }\end{array}$ & MK680106 & 98.71 & Salinicoccus roseus \\
\hline 8. & MSW2 & Seawater & MK680105 & 99.42 & Idiomarina sediminum \\
\hline 9. & CSW3 & Seawater & MK680104 & 99.34 & Idiomarina sediminum \\
\hline 10. & BSP1 & $\begin{array}{l}\text { Unidentified } \\
\text { violet Sponge }\end{array}$ & MK680103 & 99.41 & $\begin{array}{l}\text { Pseudomonas } \\
\text { aeruginosa }\end{array}$ \\
\hline 11. & $\mathrm{CO} 8$ & Conus miles & ND & & ND \\
\hline 12. & DA1 & Seawater & ND & & ND \\
\hline 13. & BSE6.1 & Sediment & MK951781 & 99.71 & Streptomyces sp. \\
\hline 14. & S2.1 & Sediment & MK680108 & 99.77 & Zooshikella marina \\
\hline 15. & BSC & Holothuria artra & MK680112 & 96.64 & Serratia marcescens \\
\hline 16. & $\mathrm{AB} 4$ & Acetabularia acetabulum & MK680101 & 95.65 & $\begin{array}{l}\text { Photobacterium } \\
\text { ganghwense }\end{array}$ \\
\hline 17. & AB5 & Acetabularia acetabulum & MK680102 & 97.87 & $\begin{array}{l}\text { Photobacterium } \\
\text { ganghwense }\end{array}$ \\
\hline
\end{tabular}

RAPD investigation revealed that out of twenty tested RAPD primers, OPA-07 GAAACGGGTG, OPA-12 TCGGCGATAG, OPB-01 GTTTCGCTCC, OPB-15 GGAGGGTGTT, OPC-05 GATGACCGCC, OPD-10 GGTCTACACC and OPE-11 GAGTCTCAGG have generated specific banding patterns for BSE6 \& S2 bacterial strains (Figure 10c,d). Similarly, restriction enzymes AluI, HindIII, BamHI and EcoRI also resulted the different banding pattern confirming that these two bacterial strains are distinct each other (Figure 10b).

The first description of genus Zooshikella was reported in 2003 as Zooshikella ganghwensis gen. nov., sp. nov., under the class gamma-Proteobacteria [30]. Type strains of Z. ganghwensis were first isolated from coastal sediment sample collected from the getbol of Ganghwa Island in Korea [30]. Phylogenetically, Zooshikella shows a close proximity and lineage with red pigmented bacterial genus Hahella. So far only three species, Z. ganghwensis JC2044 ${ }^{\mathrm{T}}$ [30], Z. marina JC333 ${ }^{\mathrm{T}}$ [31], and Z. rubidus S1-1 [24] have been reported under the genus Zooshikella; while taxonomic status of the latter species name is yet to be confirmed by polyphasic taxonomic approach. All the three species of this genus Zooshikella were isolated from coastal sediment samples alone. The genus Zooshikella has not been explored much, making it an unexplored source of pharmaceutically important pigment compounds and food grade colorants. The major chemical constituents reported in the Zooshikella species were prodigiosin and cycloprodigiosin. These compounds have displayed potential biological activities such as anti-oncogenic activity against human melanoma cells [24] and other human cancer cell lines, SK-BR-3, HCT-116, SK-OV-3, HeLa, HepG2, and SK-MEL-5 [26], antibacterial activity against several microbial species [24,32,33], and dyeing properties [34]. Comparative to Zooshikella type strain JC2044, 
strain S2.1 is able to tolerate maximum temperature of $35{ }^{\circ} \mathrm{C}$ and displayed antibacterial inhibition activity range of 20-28 mm against investigated pathogens. The two strains, S2.1 and BSE6.1 producing prodigiosin-like pigments are very close to already known strains on the basis of 16S rRNA gene sequences and the observed antibacterial effect of prodigiosin pigment has been also reported in previous studies.

Previous study reported that the majority of pigmentation was remained in the microbe-rich mucus pellet of rays [35]. However, we have not found such an incident for fish samples, but it was evident that the pigmented bacterial population was greater in sediment, invertebrates and seawater samples. The inhibited growth of bacteria on media containing seawater indicates that they might be of terrestrial origin [36], and this incident was not observed for any of pigmented bacterial isolates in this study. Antagonistic effects on indigenous pigment bacterial isolates were observed in a previous study [37], however, in the present study such case was not observed. The RAPD primers OPA-07 GAAACGGGTG, OPA-12 TCGGCGATAG, OPB-01 GTTTCGCTCC, OPB-15 GGAGGGTGTT, OPC-05 GATGACCGCC, OPD-10 GGTCTACACC and OPE-11 GAGTCTCAGG and restriction enzymes AluI, HindIII, BamHI and EcoRI could be used for effective differentiation of members of Zooshikella and Streptomyces species in Andaman waters.

Whole genome sequencing of strain S2.1 using Illumina platform revealed absence of 365 genes and significantly 1989 genes were not detected in KEGG pathway database (Ramesh et al., 2019c). Thus, strain S2.1 was proposed as a novel species as Z. andamani which is also yet to be verified by polyphasic taxonomical approach. While, strain BSE6.1is not similar to prodigiosin producing Streptomyces griseoviridis, thus whole genome of BSE6.1 is under process to confirm the novelty level of this strain. Conversely, the pigments of strain S2.1 and BSE6.1 can be used as food colorants and as natural stains in laboratorial purposes. Further, Zooshikella sp. strain S2.1 and Streptomyces sp. strain BSE6.1 could be used for genetic engineering studies to improve pigment production for various applications.

\section{Conclusions}

The present project work report reveals the dominant distribution of pigment bacteria in sediment and invertebrate samples collected from different locations in South Andaman. Among different pigment types, red, orange, brown and yellow were predominate pigment type bacterial isolates were isolated. Among 17 study locations, pigment bacteria were higher and varied pigment types were observed in Burmanallah station. Two red pigment producing strains S2.1 and BSE6.1 have displayed promising multifaceted applications. Thus, these two strains are selected for further applications. In due course of time, these strains will be deposited in Microbial Type Culture Collection, India for the benefit of researchers and industries.

The advanced biotechnological techniques would open new avenues for large scale industrial production of natural pigments for various applications and to substitute the synthetic pigments. This study provides a detailed data on genetic diversity of several potential marine pigmented bacterial species like Zooshikella and Streptomyces, and possibility of isolation of some novel species from diverse marine samples of Andaman Islands. The isolated cultures are maintained as a culture collection for future applications and reference. Based on the baseline investigations, it is evident that pristine Andaman Islands offer a wide variety of pigmented bacteria with potential biomedical applications. Thus, research on this aspect is needed to be extended to explore novel pigment bacteria which will offer natural pigments for food and drug applications. 
Supplementary Materials: The following are available online at http://www.mdpi.com/2076-2607/8/4/556/s1.

Author Contributions: Conceptualization, original draft preparation, data analysis, writing —review \& editing were by C.R. N.V.V., R.K., C.K.V. and L.D. did guiding-review \& editing. All authors have read and agreed to the published version of the manuscript.

Funding: This work was supported and funded by the Science and Engineering Research Board (SERB), New Delhi under the National Postdoctoral Fellowship, PDF/2016/000354 dated on 5th July 2016.

Acknowledgments: Ramesh warm thanks the SERB for awarding the National Postdoctoral Fellowship, PDF/2016/000354 dated on 5th July 2016. Also CR thanks NIOT and ANCOST for providing necessary facilities to carry out the project work.

Conflicts of Interest: The authors declare no conflicts of interest.

\section{References}

1. Aylward:, F.O.; Eppley, J.M.; Smith, J.M.; Chavez, F.P.; Scholin, C.A.; DeLong, E.F. Microbial community transcriptional networks are conserved in three domains at ocean basin scales. PNAS 2015, 112, 443-448. [CrossRef]

2. Grossart, H.; Thorwest, M.; Plitzko, I.; Brinkhoff, T.; Simon, M.; Zeeck, A. Production of a blue pigment (Glaukothalin) by marine Rheinheimera spp. Int. J. Microbiol. 2009, 2009, 701735. [CrossRef]

3. Soliev, A.B.; Hosokawa, K.; Enomoto, K. Bioactive pigments from marine bacteria: Applications and physiological roles. Evid. Based. Complement. Alternat. Med. 2011, 2011, 670349. [CrossRef]

4. Ramesh, C.H.; Vinithkumar, N.V.; Kirubagaran, R.; Venil, C.K.; Dufosse, L. Multifaceted applications of microbial pigments: Current knowledge, challenges, and future directions for public health implications. Microorganisms 2019, 7, 186. [CrossRef]

5. Ramesh, C.H.; Vinithkumar, N.V.; Kirubagaran, R. Marine pigmented bacteria: A prospective source of antibacterial compounds. J. Nat. Sci. Biol. Med. 2019, 10, 104-113. [CrossRef]

6. Chin, Y.W.; Balunas, M.J.; Chai, H.B.; Kinghorn, A.D. Drug discovery from natural sources. AAPS J. 2006, 8 , E239-E253. [CrossRef] [PubMed]

7. Venil, C.K.; Zakaria, Z.A.; Ahmad, W.A. Bacterial pigments and their applications. Process. Biochem. 2013, 48, 1065-1079. [CrossRef]

8. Numan, M.; Bashir, S.; Mumtaz, R.; Tayyab, S.; Rehman, N.U.; Khan, A.L.; Shinwari, Z.K.; Al-Harrasi, A. Therapeutic applications of bacterial pigments: A review of current status and future opportunities. 3 Biotech 2018, 8, 207. [CrossRef] [PubMed]

9. Ramesh, C.; Mohanraju, R.; Murthy, K.N.; Karthick, P. Molecular characterization of marine pigmented bacteria showing antibacterial activity. Indian J. Mar. Sci. 2017, 46, 2081-2087.

10. Brown, A.E.; Smith, R.H. Benson: Microbiological Applications Lab Manual, 14th ed.; The McGraw-Hill Companies: New York, NY, USA, 2016.

11. Stafsnes, M.H.; Bruheim, P. Pigmented Marine Heterotrophic Bacteria. In Marine Biomaterials; Kim, S.K., Ed.; CRC Press: Boca Raton, FL, USA, 2013; pp. 117-148.

12. Ramesh, C.; Anwesh, M.; Vinithkumar, N.V.; Kirubagaran, R. Draft genome sequence of marine sediment-derived red pigmented bacteria Zooshikella sp. strain S2.1 with potential biomedical applications. Genomics 2019, 112, 805-808. [CrossRef]

13. Lane, D.J. 16S/23S rRNA sequencing. In Nucleic Acid Techniques in Bacterial Systematics; Stackebrandt, E., Goodfellow, M., Eds.; John Wiley \& Sons Inc.: New York, NY, USA, 1991; pp. 115-175.

14. Tamura, K.; Stecher, G.; Peterson, D.; Filipski, A.; Kumar, S. MEGA6: Molecular evolutionary genetic analysis version 6.0. Mol. Biol. Evol. 2013, 30, 2725-2729. [CrossRef] [PubMed]

15. Gontcharova, V.; Youn, E.; Wolcott, R.D.; Hollister, E.B.; Gentry, T.J.; Dowd, S.E. Black box chimera check (B2C2): A windows-based software for batch depletion of chimeras from bacterial $16 \mathrm{~S}$ rRNA gene datasets. Open Microbiol. J. 2010, 4, 47-52. [CrossRef] [PubMed]

16. Thompson, J.D. CLUSTAL W: Improving the sensitivity of progressive multiple sequence alignment through sequence weighting, position-specific gap penalties and weight matrix choice. Nucleic Acids Res. 1994, 22, 4673-4680. [CrossRef] [PubMed]

17. Tamura, K.; Nei, M.; Kumar, S. Prospects for inferring very large phylogenies by using the neighbor-joining method. Proc. Natl. Acad. Sci. USA 2004, 101, 11030-11035. [CrossRef] 
18. Felsenstein, J. Confidence limits on phylogenies: An approach using the bootstrap. Evolution 1985, 39, 783-791. [CrossRef]

19. Wietz, M.; Mansson, M.; Gotfredsen, C.H.; Larsen, T.O.; Gram, L. Antibacterial compounds from marine Vibrionaceae isolated on a global expedition. Mar. Drugs 2010, 8, 2946-2960. [CrossRef]

20. Bauer, A.W.; Kirby, W.M.M.; Sherris, J.S.; Turk, M. Antibiotic susceptibility by standardized single disc method. Am. J. Clin. Pathol. 1966, 45, 493-496. [CrossRef]

21. CLSI. Methods for Dilution Antimicrobial Susceptibility Tests for Bacteria that Grow Aerobically; CLSI: Wayne, PA, USA, 2006; Volume CLSI documents M27-S3; p. 940.

22. Wiegand, I.; Hilpert, K.; Hancock, R.E.W. Agar and broth dilution methods to determine the minimal inhibitory concentration (MIC) of antimicrobial substances. Nat. Protocol. 2008, 3, 163-175. [CrossRef]

23. Pouchert, C.J. The Aldrich Library of FT-IR Spectra, 1st ed.; Aldrich: Milwaukee, WI, USA, 1985.

24. Lee, J.S.; Kim, Y.S.; Park, S.; Kim, J.; Kang, S.J.; Lee, M.H.; Ryu, S.; Choi, J.M.; Oh, T.K.; Yoon, J.H. Exceptional production of both prodigiosin and cycloprodigiosin as major metabolic constituents by a novel marine bacterium, Zooshikella rubidus S1-1. Appl. Environ. Microbiol. 2011, 77, 4967-4973. [CrossRef]

25. Siva, R.; Subha, K.; Bhakta, D.; Ghosh, A.R.; Babu, S. Characterization and enhanced production of prodigiosin from the spoiled coconut. Appl. Biochem. Biotechnol. 2012, 166, 187-196. [CrossRef]

26. Oh, E.J.; Kwon, J.H.; Kim, S.Y.; In, S.J.; Lee, D.G.; Cha, M.Y.; Kang, H.C.; Hwang-Bo, J.; Lee, Y.H.; Chung, I.S.; et al. Red pigment produced by Zooshikella ganghwensis inhibited the growth of human cancer cell lines and MMP-1 gene expression. Appl. Biol. Chem. 2016, 59, 567-571. [CrossRef]

27. Song, M.J.; Bae, J.; Lee, D.S.; Kim, C.H.; Kim, J.S.; Kim, S.W.; Hong, S.I. Purification and characterization of prodigiosin produced by integrated bioreactor from Serratia sp. KH95. J. Biosci. Bioeng. 2006, 101, 157-161. [CrossRef] [PubMed]

28. Fehér, D.; Barlow, R.S.; Lorenzo, P.S.; Hemscheidt, T.K. A 2-Substituted Prodiginine, 2-(p-Hydroxybenzyl) prodigiosin, from Pseudoalteromonas rubra. J. Nat. Prod. 2008, 71, 1970-1972. [CrossRef] [PubMed]

29. Wang, Y.; Nakajima, A.; Hosokawa, K.; Soliev, A.B.; Osaka, I.; Arakawa, R.; Enomoto, K. Cytotoxic prodigiosin family pigments from Pseudoalteromonas sp. 1020R isolated from the pacific coast of Japan. Biosci. Biotechnol. Biochem. 2012, 76, 1229-1232. [CrossRef] [PubMed]

30. Yi, H.; Chang, Y.; Oh, H.W.; Bae, K.S.; Chun, J. Zooshikella ganghwensis gen. nov., sp. nov., isolated from tidal flat sediments. Int. J. Syst. Evol. Microbiol. 2003, 53, 1013-1018. [CrossRef]

31. Ramaprasad, E.V.V.; Bharti, D.; Sasikala, C.; Ramana, C.V. Zooshikella marina sp. nov. a cycloprodigiosin-and prodigiosin-producing marine bacterium isolated from beach sand. Int. J. Syst. Evol. Microbiol. 2015, 65, 4669-4673. [CrossRef]

32. Jafarzade, M.; Yahya, N.A.; Mohamad, S.; Usup, G.; Ahmad, A. Isolation and characterization of pigmented bacteria showing antimicrobial activity from Malaysian marine environment. Mal. J. Microbiol. 2013, 9, 152-160. [CrossRef]

33. Rehman, Z.; Alam, I.; Kamau, A.A.; Bajic, V.B. Genome sequence analysis of Zooshikella ganghwensis strain VG4 and its potential for the synthesis of antimicrobial metabolites. Biotechnol. Rep. 2018, 19, e00278. [CrossRef]

34. Kim, Y.; Choi, J. Dyeing properties of microbial prodiginine from Zooshikella rubidus for silk fabrics. Fibers Polym. 2015, 16, 1981-1987. [CrossRef]

35. Ritchie, K.B.; Schwarz, M.; Mueller, J.; Lapacek, V.A.; Merselis, D.; Walsh, C.J.; Luer, C.A. Survey of antibiotic-producing bacteria associated with the epidermal mucus layers of rays and skates. Front. Microbiol. 2017, 8, 1050. [CrossRef]

36. Hakvåg, S.; Fjærvik, E.; Klinkenberg, G.; Borgos, S.E.F.; Josefsen, K.D.; Ellingsen, T.E.; Zotchev, S.B. Violacein-producing Collimonas sp. from the sea surface microlayer of costal waters in Trøndelag, Norway. Mar. Drugs 2009, 7, 576-588. [CrossRef] [PubMed]

37. Brinkhoff, T.; Bach, G.; Heidorn, T.; Liang, L.; Schlingloff, A.; Simon, M. Antibiotic production by a Roseobacter clade-affiliated species from the German Wadden Sea and its antagonistic effects on indigenous isolates. Appl. Environ. Microbiol. 2004, 70, 2560-2565. [CrossRef] [PubMed]

(C) 2020 by the authors. Licensee MDPI, Basel, Switzerland. This article is an open access article distributed under the terms and conditions of the Creative Commons Attribution (CC BY) license (http://creativecommons.org/licenses/by/4.0/). 